\title{
Going Back-to-School in Vocational Education and Training: Introduction
}

\author{
Louis Cournoyer*1, Geneviève Fournier ${ }^{2}$, and Jonas Masdonati ${ }^{3}$ \\ ${ }^{1}$ Université du Québec à Montréal, 1205, rue Saint-Denis, N4900, Montreal (Québec), Canada \\ ${ }^{2}$ Département des fondements et pratiques en éducation, Université Laval, 2320, rue des \\ Bibliothèques, Québec, QC G1V 0A6, Canada \\ ${ }^{3}$ Institute of Psychology, University of Lausanne, Quartier UNIL-Mouline, Géopolis 4116, \\ CH-1015 Lausanne, Switzerland
}

Received: 24.10.2017; Accepted: 07.11.2017; Published: 22.11.2017

\section{Introduction}

Today's labor market is one of constant and unpredictable change because of the social, economic, cultural, technological and political transformations it depends on. This creates greater pressure on the productivity and competitiveness of organizations, but also on workers whose careers are subject to more frequent and complex pressures, bifurcations and transitions (Blustein, 2008; Fouad \& Bynner, 2008; Fournier, Poirel, \& Lachance, 2016). New organizations expectations and needs in terms of workforce qualifications open demands on more advanced knowledge and skills among workers (Adamuti \& Sweet, 2008; Agrawal, 2012), as well on adult vocational and training education (VET) institutions (Hämäläinen, Cincinnato, Malin, \& De Wever, 2014; Nore \& Lahn, 2014). In this respect, VET plays a key role in the social development of societies and communities in a context of market globalization and continuous technological innovations (Billett, 2014; Bosch \& Charest, 2008; Grubb, 2006). VET helps to promote the socioprofessional integration of young people and adults in many countries, the pursuit of careers more oriented towards own life aspirations, as well as preventing social exclusion and poverty (Billett, 2004; Cournoyer, Fortier, \& Deschenaux, 2016; Fournier, Lachance, \& Bujold, 2009; Virolainen \& Stenström, 2014).

VET's orientations, roles and learning models in different nations vary greatly and are largely based on public and educational policies in place, as well as on the way in which the different social actors involved (governments, training institutions, employers, unions, etc.) collaborate or not. Public policies and measures put in place to ensure

*Corresponding author: cournoyer.louis@uqam.ca

ISSN: $2197-8646$

http://www.ijrvet.net 
the development of VET competences implies, as is the case in countries like Germany, Norway, Sweden, Finland and Denmark, an active participation of employers, unions, academic institutions and government representatives to ensure quality and mobility, while in other places, such as England, France, Spain, Portugal, Italy and Greece, the role played by these groups are less integrated (Brockmann, Clarke, \& Winch, 2008; Eichhorst, Rodrigues-Planas, Simdl, \& Zimmerman, 2012; Virolainen \& Stenström, 2014). As well, in some countries, such as Norway, Denmark, Switzerland and Germany, VET is offered, through dual and holistic models that encompass a continuous alternation of learning experiences within academic institutions and work organizations. In other countries (ex., Canada, United States, England, France), these apprenticeships respond to a more sequential and linear model of academic experience complemented by internships within work organizations (Bosch \& Charest, 2008; Brockmann et al., 2008; Eichhorst et al., 2012). Also, some VET apprenticeship models rely on the joint acquisition of general knowledge transferable to several professional activities and others that are applied solely and specifically to a trade, while in other places the focus is mainly on the latter (Brockmann et al., 2008). VET success is thus based on the one hand on a continuous alternation of learning between the school and work organization environments and on the partnership between the different social actors concerned by education and employment (governments, employers, schools). On the other hand, it depends on the ability to adjust to technological change and to acquire the skills required by the labor market, the promotion of this type of education (versus higher education) among youth and adult populations, as well as on favorable employment opportunities and conditions (Eichhorst et al., 2012; Grubb, 2006). VET is an interesting training option for individuals looking to find, in a relatively short period, better working conditions and employment outlooks, as well as for employers looking for skilled and productive workers able to adapt to labor market and technological transformations (Hoeckel, 2008). In addition, it seems that these benefits depend greatly on the quality of the school-to-work transition that individuals, institutions, employers and policy makers are able to ensure (Billett, 2014; Goyer, 2017; Grubb, 2006; Hart, 2017; Hofman, Stalder, Tschan, \& Häfeli, 2014; Nurmi, Salmela-Aro, \& Koivisto, 2002).

However, in many countries, VET suffers from a lower status and negative social value attributions compared to higher education (Billett, 2014; Lovsin, 2014; Virolainen \& Stenström, 2014). It is often considered as an interesting and safe option for students with learning, motivation and retention difficulties. These latters are indeed often perceived as having more manual than intellectual vocational interests and competencies and thus have more or less the choice of their formation. (Deschenaux, 2007; Eichhorst et al., 2012). However, it seems that VET is perceived differently and more positively among young people and adults who voluntarily choose to engage in it (Cournoyer et al., 2016; Krahn \& Taylor, 2005).

Despite that, several categories of individuals at different moments of their lives are attracted by VET. Initially and mainly organized to welcome and train adolescents and young adults at the end of their compulsory schooling, the transformations and the upheavals of the economies and the labor market bring - or rather bring back - to school more experienced workers (Harris, Sumner, \& Rainey, 2005; Lehmann, Taylor, \& Wright, 
2014; Molgat, Deschenaux, \& LeBlanc, 2011). As pointed out by Masdonati, Fournier and Pineault (2015), VET offers very interesting conditions and perspectives for people wishing to quickly acquire qualifying training to enter a new career. As an adult, going back-to-school in VET is often associated with a life course marked by more or less satisfactory job tasks and conditions, parallel relational, conjugal, parental and financial tensions, as well as other personal difficulties or challenges: psychological and physical health problems, single parenthood, social assistance, work accidents, immigration, etc. (Cournoyer et al., 2016; Deschenaux \& Roussel, 2006; Lehmann et al., 2014; Polesel, 2010). The academic pathways of these individuals are often accompanied by difficulties in terms of academic perseverance, motivation and confidence (Lehmann et al., 2014; Vonthron, Lagabrielle, \& Pouchard, 2007). VET thus makes it possible for these adults to become more skilled, confident and autonomous in a specific field of action, bringing concrete, safe and satisfying sense of self, as well as better work conditions and professional outlook (Billett, 2014; Cournoyer et al., 2016; Dormeier, Freire, \& Giang, 2012; Field, Hoeckel, Kish, \& Kuczera, 2009; Molgat et al., 2011; Rousseau, Théberge, Bergevin, Tetrault, Samson, Dumont, \& Myre-Bisaillon, 2010). VET can allow them to quickly learn and acquire skills, to complete rather short duration schooling and to learn in a more concrete, practical and applied way (Brockmann et al., 2008; Powell, Bernhard, \& Graf, 2012).

The continuous evolution and transformation of the labor market, the emergence of new technologies, the renewed needs of employers, and the constant increase of adult populations with more diverse characteristics and life paths call for new knowledge. practices, skills and teaching conditions in VET. Teachers play an important role in the ability to train skilled and effective workers who are able to transfer their knowledge and skills appropriately to different work situations. To do so, it is as important for them to have renewed and better adapted knowledge and skills to better meet new standards and meet the learning needs of more diverse student populations, as well as to benefit from climates and teaching conditions. favorable to the intended objectives (Grubb, 2006; Hinrichs, 2014; Wärvik, 2013).

Career transitions are also influenced by uncertainty and constant changes, among other things, according to the evolution of the economy and the labor market, which generates complex situations of more or less voluntary choice (Fouad \& Bynner, 2008). This is the case for adults who decide, at some point in their lives, to make a career change that will lead them to go back-to-school in VET. This type of change comes with more or less linear transitive phases of engagement and motivated choice, preparation and exploration, but also of recoil, latency, readjustment, and doubt (Donahue, 2007; Heppner \& Scott, 2006; Ibarra, 2006; Negroni, 2007). According to Cournoyer et al. (2016), VET career-oriented adults are frequently motivated by the search for a project that can fully satisfy their personality, but they are also looking for a certain continuity in their interests and experiences, as well as security and personal stability within a job and a work organization that can help them to maintain or obtain the quality of life they expect including with their family and close ones.

While older adults are becoming more numerous in VET programs population, as their characteristics and pathways are more complex and diversified, little research until 
now have focused on a better understanding of the realities, issues, processes and effects of decisions, transitions and changes that accompany graduation efforts (Cournoyer et al., 2006; Hostetler, Sweet, \& Moen, 2007), both at the individual, institutional or social levels. This special issue aims to offer a better understanding of this phenomenon from different perspectives. In this regard, the authors of this issue contribute to answer to questions such as: Who are the adult students who return to VET and what characterize them? What are their experiences and processes of decision making, change and adaptation in VET? How do public policies, education systems and learning models influence how to qualify for a trade? This issue is composed of five articles.

The first paper, titled "Why Returning to VET? Results of a Qualitative Comparative Study about English and German Car Mechatronics", by Ericka Gericke, proposes a comparative research on educational choices and especially the influence of class on VET decision-making from a subject-oriented perspective. Gericke has decide to work with the concept of "biographical occupation orientations" in order to explore the experience of eleven English and German car mechatronics. These two populations have been selected because of their significant differences in their VET systems, the first characterised of dual and holistic training, the second characterised of a diffuse, but flexible structure. As mentioned by the author, the concept of biographical occupation orientations acts as a mediator between the structure (VET system, vocational requirements) and action (professional identity, processes of self constitution) levels. Gericke aims to answer two main research questions, one dealing with biographical occupation orientations developed by English and German mechatronics, the other with how their development are affected by the two VET systems. Emerging from a Grounded Theory methodology, findings show and detail patterns about the interplay of biographical occupation orientations with subjective perceptions of each VET system and the decision for returning to VET, and also how the national vocational and education training system influences the biographical occupation orientations process.

The second article, titled "Decision-Making Rationales among Quebec VET Student Aged 25 and Older", by Louis Cournoyer and Frédéric Deschenaux, focuses on adults aged 25 and over making the decision to return to school in VET. These adults have personal, academic, professional and other (family, marital, social) life paths marked by a series of events, encounters, conjunctures, bifurcations, breaks, leading them to consider VET as a possible salvation option for their future and the improvement of their living conditions. Based on the interviews with 30 adults, which traced their educational and professional life path, Cournoyer and Deschenaux sought to identify the rationales shared by the majority of them. To identify, detail and illustrate these rationales, the contents of interviews were analysed according to a decision-making model developed by the authors and their collaborators. This model articulates two complementary perspectives, one biographical, focusing on the study of life courses and personal projects, the other interactionist, focusing on contextual strengths and strategies 'adjustment. Five rationales are identified as a result of the analysis, which are also decision-making actions by these adults.

The third paper, titled "The Reasons Behind a Career Change Through Vocational Education and Training", by Jonas Masdonati, Geneviève Fournier, and Imane Z. Lahrizi, 
proposes an exploration and a categorisation of the reasons underlying career changes through VET. The research focuses on 30 VET students from the Province of Quebec, Canada, aged 25 to 45 , enrolled in a program with a goal of career change. The notion of career change, from a psychosocial perspective, is at the heart of the researchers' approach. Results stress major motives of career change through a return to VET, one reactive, the other proactive, as well as for each of them different categories of reasons for change. Masdonati, Fournier and Lahrizi point out the importance of going beyond the characterization of voluntary or involuntary change in these adults, but rather to dwell on the perceptions of mastering their decision with regard to the influences of contexts. Finally, they suggest that informal learning processes are already in place even before the decision to make a formal enrollment in a VET program Finally, the results highlight the heterogeneity and complexity of older student populations in vocational training, as well as the importance of better understanding the reasons for career change in order to conceive effective interventions in this regard.

The fourth article, titled "When Work Comes First: Young Adults in Vocational Education and Training in Norway", by Anna Hagen Tønder and Tove Mogstad Aspøy, explores the personal trajectories of 25- to 35-year-old adult students $(n=34)$ enrolled in two important VET programs in Norway, one in Carpentry and the other in Child Care and Youth Work. The first is a male-dominated occupation, the second a femaledominated one. Since 1994, VET in Norway has been integrated into upper secondary education where pupils aged 15 or 16 can then choose between this type of program or a general academic program. Like Denmark, Norway offers a dual apprenticeship system where education in an academic environment is combined with the vocational education provided by employers in the workplace. However, like many other countries in the world, VET is often perceived as a terminal pathway - a blind alley. In addition, recent VET surveys in Norway report significant dropout rates and the displacement of many apprenticeship-type students to study options that may facilitate access to higher education. Researchers stress the importance of better understanding the trajectories of VET adult students and the reasons why people choose to pursue VET as a "second chance" rather than the standardised route drawn up by policy makers. This opens discussion on the idea of providing institutional structures that can support workers just as much in the workplace as in school. For both the Carpentry and Child Care and Youth Service students, different trajectories were identified, which bring a better and more nuanced understanding of the motivations guiding the process leading to the decision to return to VET, in relation to their family history, their educational experiences and their transitions from school to work.

The last and fifth paper, titled "VET again: Now as a VET Teacher", by Henriette Duch, and Karen E. Andreasen, examines the learning trajectories of two Danish vocational teachers who choose to complete a mandatory training course introduce in 2010. Teachers have to adapt themselves to different student's profiles that comes along with various employment experiences, different ages and with very diverse personal and social characteristics. To be able to face this new VET realities, teachers who already have different qualifications and work experiences background, have to acquire new knowledge and pedagogical and didactical skills. Duch and Andreasen examine the learning 
trajectories of VET teachers according to three forms of coherence, namely biography (the link between their current knowledge and their previous experiences), transitions (relationships between knowledge and skills acquired before and after the obligatory course experience), as well as the program (description of learning achieved in relation to its content). The results suggest that the course experience partly transforms teaching content and strategies according to the specific contexts of the trainers.

Social, economic, technological, cultural and political transformations affect the evolution of the labor market, generate more specific employers' needs and expectations, as well as training institutions that train and qualify future workers. Although worldwide education systems are historically structured to accompany adolescents and young adults to a successful entry into the labor market, educational institutions have nowadays to deal with annual increases of older adults who decide to return to school in order to change career or to increase their professional skills. Unlike young people who are often reluctant to pursue VET and tend to prefer higher education, many adults see this type of program as an opportunity to acquire quickly a short-term, practice-based training opportunity, with school and work apprenticeships experience, in a variety of job-creating business sectors. This special issue focuses specifically on those adults who, at some point in their lives, choose to return to VET in order to positively change their lives, at the level of more challenging work tasks, better working conditions, safer work and life to ensure their well-being and that of their loved ones. The same goes for some teachers who decide or have to go back to school to adjust their teaching strategies to these adult students. Among the elements that must be taken into account in each of the articles is that career paths, trajectories, decision-making processes, transitions or changes are based on factors and variables that are both individual, interpersonal, social and contextual. It is also important to consider experiences, encounters, events and situations that people go through throughout their lives. Individuals, teachers and other school professionals, as well as public decision-makers, are invited to understand adults' return to VET as a complex and challenging experience. 


\section{References}

Adamuti-Trache, M., \& Sweet, R. (2008). Vocational training choices of women: Public and private colleges. Gender and Education, 20(2), 167-182.

Agrawal, T. (2012). Vocational education and training in India: challenges, status and labour market outcomes. Journal of Vocational Education 85 Training, 64(4), 453474.

Billett, S. (2014). The standing of vocational education: Sources of its societal esteem and implications for its enactment. Journal of Vocational Education $\&$ Training, $66(1), 1-21$.

Blustein, D. L. (2008). The role of work in psychological health and well-being: a conceptual, historical, and public policy perspective. American Psychologist, 63(4), 228.

Bosch, G., \& Charest, J. (2008). Vocational training and the labour market in liberal and coordinated economies. Industrial relations journal, 39(5), 428-447.

Brockmann, M., Clarke, L., \& Winch, C. (2008). Knowledge, skills, competence: European divergences in vocational education and training (VET) - the English, German and Dutch cases. Oxford review of education, 34(5), 547-567.

Bujold, C., \& Fournier, G. (2008). Occupational representations of workers in nonstandard and precarious work situations. Journal of career assessment, 16(3), 339-359.

Charbonneau, J. (2006). Réversibilités et parcours scolaires au Québec. Cahiers internationaux de sociologie, 120, 111-131.

Cournoyer, L. (2011). Le rôle des relations sociales sur l'évolution des projets professionnels. Dans S. Bourdon et J. Charbonneau (dir.), Regard sur... les jeunes et leurs relations, 141-156. Québec: Presses de l'Université Laval.

Cournoyer, L., Fortier, S., \& Deschenaux, F. (2016). Dimensions traversant le processus décisionnel conduisant à la poursuite d'études formation professionnelle au Québec et en Ontario : entre expériences passées et espoirs salvateurs. L'Orientation scolaire et professionnelle, 45(4), 449-472.

Deschenaux, F. (2007). La formation professionnelle au secondaire : une voie de relégation sur le marché de l'emploi. Bulletin de l'Observatoire jeunes et société, 6(4), 1-2.

Deschenaux, F., \& Roussel, C. (2010). De la pratique à l'enseignement d'un métier en formation professionnelle au Québec : un passage volontaire. Pensée plurielle, $24(2), 131-143$.

Donohue, R. (2007). Examining career persistence and career change intent using the Career Attitudes and Strategies Inventory. Journal of Vocational Behavior, 70, 259276.

Dormeier Freire, A., \& Giang, H. T. (2012). The role of family in vocational education and training choices: a case study in Vietnam. International Studies in Sociology of Education, 22(3), 237-257.

Eichhorst, W., Rodríguez-Planas, N., Schmidl, R., \& Zimmermann, K. F. (2012). A roadmap to vocational education and training systems around the world. Bonn, Germany: Institute of Labor Economics (IZA). 
Field, S., Hoeckel, K., Kis, V., \& Kuczera, M. (2009). Learning for jobs. OECD policy review of vocational education and training. Initial Report. Paris, France : OECD.

Fouad, N. A., \& Bynner, J. (2008). Work transitions. American Psychologist, 63(4), 241-251.

Fournier, G., Poirel, E., \& Lachance, L. (2016). Éducation et vie au travail (Tome 2) : Perspectives contemporaines sur les parcours de vie professionnelle. Québec: Les Presses de l'Université Laval.

Fournier, G., Lachance, L., \& Bujold, C. (2009). Nonstandard career paths and profiles of commitment to life roles : A complex relation. Journal of Vocational Behavior, $74,321-331$.

Grubb, W. N. (2006). Vocational education and training: Issues for a thematic review. Paris: OECD.

Hämäläinen, R., Cincinnato, S., Malin, A., \& De Wever, B. (2014). VET workers' problem-solving skills in technology-rich environments: European approach. International journal for research in vocational education and training, 1(1), 57-80.

Harris, R., Sumner, R., \& Rainey, L. (2005). Student Traffic: Two-Way Movement between Vocational Education and Training and Higher Education. Adelaide, Australia: National Centre for Vocational Education Research.

Heppner, M. J., \& Scott, A. B. (2006). Career transitions. In J. H. Greenhaus \& G.A. Callanan (Eds.), Encyclopedia of Career Development (pp. 157-159). Thousand Oaks, CA: Sage.

Hinrichs, A. C. (2014). Predictors of collateral learning transfer in continuing vocational training. International journal for research in vocational education and training, $1(1), 35-56$.

Hoeckel, K. (2008). Costs and benefits in vocational education and training. Paris: Organisation for Economic Cooperation and Development.

Hofmann, C., Stalder, B. E., Tschan, F., \& Häfeli, K. (2014). Support from Teachers and Trainers in Vocational Education and Training: The Pathways to Career Aspirations and Further Career Development. International journal for research in vocational education and training, 1(1), 1-20.

Hostetler, A. J., Sweet, S., \& Moen, P. (2007). Gendered career paths: A life course perspective on returning to school. Sex Roles, 56, 85-103.

Lavoie, N., Levesque, J., \& Aubin-Horth, S. (2008). Le retour en formation chez les adultes peu scolarisés: un faisceau d'obstacles. Éducation et sociétés, 22, 161-178.

Lehmann, W., Taylor, A., \& Wright, L. (2014). Youth apprenticeships in Canada: On their inferior status despite skilled labour shortages. Journal of vocational educational \& training, 66(4), 572-589.

Lhotellier, A. (2003). L'accompagnement : tenir conseil. Carriérologie, 9(1), 25-61.

Lovsin, M. (2014). The (Un) Attractiveness of vocational and technical education: theoretical background. CEPS journal: Center for Educational Policy Studies Journal, $4(1), 101-120$.

Masdonati, J., Fournier, G., \& Pinault, M. (2015). La formation professionnelle au Québec : le regard des élèves. L'Orientation Scolaire et Professionnelle, 44, 269294. 
Molgat, M., Deschenaux, F., \& LeBlanc, P. (2011). Vocational education in Canada: do policy directions dans youth trajectories always meet? Journal of Vocational Education and Training, 63(4), 505-524.

Nore, H., \& Lahn, L.C. (2014). Bridging the Gap between Work and Education in Vocational Education and Training. A study of Norwegian Apprenticeship Training Offices and E-portfolio Systems. International Journal for Research in Vocational Education and Training, 1(1), 21-34.

Nurmi, J. E., Salmela-Aro, K., \& Koivisto, P. (2002). Goal importance and related achievement beliefs and emotions during the transition from vocational school to work: Antecedents and consequences. Journal of Vocational Behavior, 60(2), 241261.

Placklé, I., Könings, K. D., Jacquet, W., Struyven, K., Libotton, A., van Merriënboer, J. J., \& Engels, N. (2014). Students' preferred characteristics of learning environments in vocational secondary education. International Journal for Research in Vocational Education and Training, 1(2), 107-124.

Powell, J. J., Bernhard, N., \& Graf, L. (2012). The emergent European model in skill formation comparing higher education and vocational training in the Bologna and Copenhagen processes. Sociology of Education, 85(3), 240-258.

Rudisill, J. R., Edwards, J. M., Hershberger, P. J., Jadwin, J. E., \& McKee, J. M. (2010). Coping with job transitions over the work life. In T. W. Miller (Ed.), Handbook of stressful transitions across the lifespan (pp. 111131). New York, NY: Springer.

Virolainen, M., \& Stenström, M. L. (2014). Finnish vocational education and training in comparison: Strengths and weaknesses. International journal for research in vocational education and training, 1(2), 81-106.

Vonthron, A. M., Lagabrielle, C., \& Pouchard, D. (2007). Le maintien en formation professionnelle qualifiante : effets de déterminants motivationnels, cognitifs et sociaux. L'orientation scolaire et professionnelle, 36 (3), 401-420.

Wärvik, G. B. (2013). The reconfiguration of adult education VET teachers: Tensions amongst organisational imperatives, vocational ideals and the needs of students. International Journal of Training Research, 11(2), 122-134. 


\section{Bibliographical Notes}

Dr Louis Cournoyer is a professor in career counseling at the Université du Quebec à Montréal. His researches focuses on the career decision-making processes of young people and adults, social relations influences on career pathways, and educational and professional trajectories.

Dr Geneviève Fournier is professor at the Université Laval, Quebec City (QC), Canada, and regular member of the Research and Intervention Center on Education and Working Life (CRIEVAT). Her research focuses on professional paths, precarious employment, personal and work transitions, meaning of work and identity construction.

Dr Jonas Masdonati is professor at the Institute of Psychology of the University of Lausanne, Switzerland, and member of the Research Center for Vocational Psychology and Career Counseling (CePCO). His research focuses on work transitions, vocational education and training, career counseling, identity construction, work values, and the meaning of work. 